Asian J. Med. Biol. Res. 2018, 4 (3), 315-322; doi: 10.3329/ajmbr.v4i3.38471

\author{
Asian Journal of \\ Medical and Biological Research \\ ISSN 2411-4472 (Print) 2412-5571 (Online) \\ www.ebupress.com/journal/ajmbr
}

\title{
Article \\ Bio-economic analysis of ESBN fishery of Kumira, the coastal area of Chittagong, Bangladesh
}

Md. Atiqul Islam Mondal ${ }^{1 *}$, M.A. Kader $^{1}$, Md. Rashed-Un-Nabi ${ }^{1}$, Abdullah Al Mamun Siddiqui ${ }^{1}$, Md Masum Billah $^{1,2,3}$ and Abdulla-Al-Asif ${ }^{4,5}$

${ }^{1}$ Institute of Marine Sciences and Fisheries, University of Chittagong, Chittagong-4331, Bangladesh

${ }^{2}$ Department of Land Management, Faculty of Agriculture, Universiti Putra Malaysia, 43400 UPM, Serdang, Selangor Darul Ehsan, Malaysia

${ }^{3}$ Department of Environmental Conservation, School of Science University of Greenwich, Medway Campus, Chatham Maritime, Kent, United Kingdom

${ }^{4}$ Department of Aquaculture, Faculty of Fisheries, Bangladesh Agricultural University, Mymensingh, 2202, Bangladesh

${ }^{5}$ Department of Fisheries and Marine Bioscience, Faculty of Biological Science and Technology, Jashore University of Science and Technology, Jashore, 7408, Bangladesh

*Corresponding author: Md Atiqul Islam Mondal, Institute of Marine Sciences and Fisheries, University of Chittagong, Chittagong-4331, Bangladesh. Phone: +8801712286263; E-mail: atiqimsf@gmail.com

Received: 07 September 2018/Accepted: 25 September 2018/ Published: 30 September 2018

\begin{abstract}
The present investigation was conducted from May to December 2005 at Kumira, the representative area of Chittagong coast for bio-socioeconomic analysis of ESBN fishery. In catch composition of Kumira, it was observed that finfish occupied $77.03 \%$, shrimp $19.82 \%$ and crab $3.15 \%$ and the average catch per boat per day were found $16.6 \mathrm{~kg}$ in Kumira. The highest total catch per boat per day $(50 \mathrm{~kg}$ ) was found in October at Kumira. The lowest catch was found $(2 \mathrm{~kg})$ in August at Kumira. The average total catch per landing center per month was found $14805 \mathrm{~kg}$ at Kumira. The average catch per fishermen per day was found $3.39 \mathrm{~kg}$ at Kumira and the average cost per boat per month was about 7,813 Tk in the study area. Average sale per month was found over 18,713 Tk in Kumira. During the month July and August most of the fishermen were engaged in Hilsa fishing with the Hilsa gill net resulting the total catch was with ESBN lowest in those months.
\end{abstract}

Keywords: bio-economic; ESBN fishery; coastal area; Chittagong; Bangladesh

\section{Introduction}

Bangladesh is endowed with vast inland and marine water resources where large numbers of fishermen are engaged in fishing. Fisheries sector provides full time employment to an estimated 20 million people comprising of full time fishermen, small fish traders, fish transporters, processors, packers etc, (World Bank, 1998). Beside this, about 10 million people are directly or indirectly involved in fishing and /or related occupation (Nuruzzaman, 1990). The amount of fishermen in dissimilar sub-sector of fisheries amplified promptly for the former few years (Islam, 1994). One single operation of any type of fishing gear in any fishing area brings in a number of species of varies sizes and ages. It also has the complexity of multi-gear fisheries system making the situation further complex for management and conservation of the resources for sustainable use. Bangladesh has a coastline of $480 \mathrm{~km}$ along the North and North-East part of the Bay of Bengal. It has an internal estuarine water area of 7,325 sq. nautical miles up to 10 fathom depth baseline, territorial waters of 2,640 sq. nautical miles from the baseline, EEZ of 41,040 sq. nautical miles and the continental shelf of 2,480 sq. nautical miles. The total of marine water areas is about 48,365 sq. na, miles which is almost as big as the country itself. The marine catch increased from 95,000 MT in 1975-76 to 250480 MT in 1992-93 an increase of about 265\%. This 
has been possible due to Government's encouragement for the introduction of deep sea fleet of 70 trawlers (out of which 56 are in operation now) and over 6,000 mechanized boats in the Bay of Bengal yet, there remain much unexplored areas for development of off-shore fishing (Hussain, 1994; Barua et al., 2014). Increasing pressure on the costal resources has caused decline of many of the marine fish and shrimp stocks. The general belief that the continental shelf of Bangladesh is a treasure of fish for unlimited exploitation that has led to a production oriented strategy and thus resulted in some cases overexploitation of resources. The management of the EEZ is also very multifaceted. Fishery resources play a very important role in economy of Bangladesh and about $80 \%$ of the animal proteins contributed by the fisheries item. About $10.7 \%$ million people are directly or indirectly related with different fishery activity (Khan, 1982). The development and expansions of the shrimp fisheries of Bangladesh during the past ten years have been rapid. The discovery of productive fishing ground in the offshore and inshore belt of the coast, introduction of mechanized fishing boats and modern technique of bottom trawling, establishment of processing and export trade industry, and ever increasing demand for marine fishes in the international markets contributed to progressive development (Pauly and Zeller, 2016; Barua et al., 2014). However, this process of development intricate conversation and management of the exploited fish stocks for the continued sustenance of the fishery. It is also being pointed out that a systematic and planned survey on the shrimp resource of the country may be undertaken immediately to understand the extent of the resource available at present and for sustained fishing operation in the inshore region and unexploited grounds in the offshore or deep-sea region (Hussain and Hoq, 2010; Lodge et al., 2017; Ullah et al., 2014). The Bay offers a potential source of fisheries for Bangladesh. A total of 490 species of belonging to 133 families were recorded and out of these 65 species are of commercial importance (Jit et al., 2014; Amin et al., 2006; Ghosh et al., 2016; Islam, 2003; Miah et al., 2015; Johnson and Welch, 2009). Of these, Scylla serrata, Portunus pelagicus and $P$. sanguinolentus are commercially important.7 species of squid and 2 species of cattle fish or sepia have been recorded from the Bay of Bengal (Shafi and Quddus, 1982). 165 species of algae have been recorded from the Saint Martin Island, Sundarban area and the coast area of Chittagong (Islam, 1976). 17 taxa families of soft-bottom invertebrates are identified in Feni River which is adjacent to Bay of Bengal (Matin $e t$ al., 2018).

About 185 species of fish are exploited by fishermen operating estuarine set bagnets. There include 15 species of penaeid shrimp, three nonpenaeids, nine freshwater prawns, three crabs, three mollusks, 90 pelagic finfish and 62 demersal finfish (Islam et al., 1992). Many of the finfish and shellfish species are also caught by other major interactive gear, such as marine set bagnet, beach seine, push net, trammel net, bottom long line and trawl (Pauly and Zeller, 2016). A few finfish species are caught either as targeted species or by catch, by the Hilsa gillnet operated in the marine sector. The estuarine set bag net fishery has traditionally been organized as a family enterprise in many parts of Bangladesh. Three is a high degree of involvement of family members in its operation and repair. Marketing and traditional processing are also taken up by family members (Alam, 2001). The socioeconomic conditions of estuarine fisher folk was made primarily by conducting a detailed bioeconomic enquiry into the operations of ESBN fisheries and other fisheries and by examining how certain social features relations (family size participation of family members in fisheries, fishery-related and no fishery jobs distribution and ownership of fishing assets sharing of catch value etc. (Thomson et al., 1993; Habib, 2010; Mondal et al., 2018).

Since the ESBN fishery involve 55000 fishermen and 150000 dependences, it would not be easy to withdraw the nets at once stroke, leading such a big community to starvation. It appears that area and season closer would help substantially for time being. Length modal progression and the peak season for catch rates in ESBN (such as July to September and to a slightly lesser extent during February to April) show that regulating the operation of ESBN during this period even in the single stratum may be vulnerable as well as possible. The income of ESBN fishermen in this stratum is at least 3 times more than in other strata and they live much above the poverty level. They also have alternate sources of income and they live close to trammel and bottom long line fishing areas. Many of them are familiar with those methods of fishing. So transferring some of these fisher folk to trammel netting and long line would be much easier and feasible than those of the other stratum (Khan, 1994; Islam et al., 2017; Viswanathan and Jahan, 2010). The present study was conducted to evaluate the catch composition of ESBN fishery; to observe monthly fluctuation of fishes and to suggest some proper management practices of ESBN fishery resources.

\section{Materials and Methods}

\subsection{Study area and periods}

The study was conducted in an ESBN fishing village Kumira; coordinates $22^{\circ} 30^{\prime} 58.9^{\prime \prime} \mathrm{N}$ and $91^{\circ} 41^{\prime} 37.1^{\prime \prime} \mathrm{E}$ during January to December, 2005. 


\subsection{Data collection}

Biological data collection started from January to December, 2005; it included catch and species composition and prices of the various commercial fishes collected by ESBN. Data were collected by sampling fishing vessels operating the ESBN. Fishing effort of ESBN fishery was estimated. These data were then used to estimate production and revenue from the ESBN. Subsequently, this information was utilized to assess the ESBN stock in the area.

\subsection{Bio-economic analysis}

\subsubsection{Species composition of the catches}

Catch and species composition data were treated separately for each fishing gear due to the differences in fishing efficiency of catch gear and the different criteria used for sorting the shrimp into various commercial categories. Around 5 to $10 \mathrm{~kg}$ of mixed fishes was directly collected from the fish baskets when the fishing boats came to the landing center. Samples were collected for two days in every month. The days were the full moon in each month and the next day. The samples were than transport in to laboratory and finally sorted into different group or species. The weight of each group of species was taken and their percentage composition was determined.

\subsubsection{Effort estimation}

Fishing effort with the various gears was obtained from interviews with the fishing gear-operators and shrimpcollectors as well as from direct observations of the vessels engaged in fishing. Direct observations of fishing effort using bag nets were not possible as this gear is operated off a small. Fishing effort, therefore, had to be estimated based on interviews with the operators of this gear. Correct estimation of fishing effort is very important, as monthly production figures for each species are dependent on it.

\subsubsection{Sampling of catch and effort}

Catch and effort data, with details of number of craft, number of ESBN net, number of huals/day, trip/day, catch per boat, catch/trip etc. were collected at the fishing. Information on total landing for a number of boat and the number of hauls/ day, estimated number of fishing days per month, species composition of catch (by weight), and value (Taka) for each species for caught was collected at the landing sites.

\subsubsection{Estimation of total catch}

The boats were selected and fish baskets in each selected boats were counted and their weight was confirmed thought particularly discussion with the fishermen of the study area.

\subsubsection{Estimation total effort}

Monthly total effort in involved in the landing centre for ESBN fishing was calculated by the following formula: Total effort (boat) $=($ Number of boat/trip) $X($ Number of trip/day) $X$ (number of fishing/month)

\subsubsection{Estimation of Catch per Unit Effort (CPUE)}

Total CPUE was calculated with the following formula:

$\mathrm{CPUE}=(\mathrm{Catch} / \mathrm{month}) /($ boat$/ \mathrm{month})$

\subsection{Cost and earning}

Monthly data of cost and earning were collected for every month regularly. The monthly gross revenue for each species or group of shrimp or fin fish caught by a unit was obtained by multiplying the monthly mean catch rate of the species, or group, by the average price of the species/group, the number of fishing days and the average number of hauls per day.

\subsection{Data analysis}

Entire collected data were précised and inspected cautiously and documented. Afterward assortment of data, these were revised and notched. In conclusion, significant tables were prepared in accordance with the objectives of the study. Data presented mostly in the tabular form and bar chart as well as pie chart because it is simple in calculation, widely used and easy to understand. Data were analyzed using the Microsoft excel 2007. 
3. Results

\subsection{Species composition of the catches}

In the village of Kumira, finfish comprised the highest $81.23 \%$, shrimp $15.58 \%$ and crab $3.19 \%$ in the proportion of catches annually. Harpodon nehereus (Bombay duck) showed the highest $28.41 \%$ in Kumira in the annual catch of the ESBN. In composition of P. japonicus possessed $8.60 \%$, other Penaiedaee shrimp $11.22 \%$, Johnius sp. (Crooker) $21.88 \%$ \& Coila sp. 6.37\%, Polynemus paradesius $10.28 \%$ and crab 3.19\%, Gobiidae (O. rubicandus) $4.50 \%$ for the village Kumira. In kumira, ribbon fish ( $L$. savala) $0.12 \%$ comprised the lowest (Table 1 and 2).

Table 1. Seasonal variation of species composition (weight in gram) of the ESBN fishery in the Kumira.

\begin{tabular}{|c|c|c|c|c|c|c|c|c|c|}
\hline \multirow[b]{2}{*}{ Common Name } & \multicolumn{9}{|c|}{ Catch composition (weight in gram) } \\
\hline & Species/group & May & June & July & Aug & Sept. & Oct. & Nov. & Dec. \\
\hline Cat fish & Aereus sp. & & & & & & 54 & 60 & 120 \\
\hline Chiring machh & Apocryptus bato (sp.) & 35 & & 10 & 5 & ‘55 & & & \\
\hline Puiya & Bregmerossis sp. & 80 & 65 & 55 & 25 & 200 & 18 & 30 & 80 \\
\hline \multirow{2}{*}{ Flat fish } & Cynoglossus sp. & 40 & 35 & 40 & 10 & 78 & 18 & 80 & 20 \\
\hline & Coila sp. & 1440 & 1250 & 740 & 750 & 95 & 72 & 60 & 35 \\
\hline Moilla & Escualusa thorakata & 100 & 80 & 120 & 85 & & & & \\
\hline \multirow{2}{*}{ Bombay duck } & Harpodon sp. & 1360 & 960 & 570 & 588 & 335 & 1000 & 2000 & 1250 \\
\hline & Johuinius sp. & 160 & 80 & 60 & 65 & 70 & 410 & & 440 \\
\hline Ribbon fish & Lepturacanthus sp. & 0 & 20 & 0 & 0 & & 9 & 30 & 20 \\
\hline \multirow[t]{5}{*}{ Mullet } & Mugil sp & 40 & & 15 & 0 & 40 & & & \\
\hline & $\begin{array}{l}\text { Polynemus } \\
\text { paradesius }\end{array}$ & 40 & 50 & & 45 & & 840 & 360 & 800 \\
\hline & Platycephalus sp. & 60 & & 200 & 24 & 25 & & & \\
\hline & Silago sp. & 0 & 20 & 50 & 0 & 70 & & & \\
\hline & Satiphina sp. & 80 & 75 & 50 & 42 & 230 & 150 & 70 & \\
\hline Chewa & O. rubicandus & 340 & 250 & & 254 & 15 & 18 & 280 & 50 \\
\hline Crab & Crab & 20 & 30 & 50 & 55 & 240 & 16 & 100 & 50 \\
\hline \multirow[t]{5}{*}{ Shrimp } & P. japonicus & 340 & 220 & 250 & 220 & 250 & 310 & 340 & 350 \\
\hline & P. merguensis & 80 & 60 & 50 & 62 & 80 & 100 & 340 & 160 \\
\hline & P. teneupes & 40 & & & 0 & & & & \\
\hline & P. stylifera & 80 & 50 & 75 & 0 & 230 & 5 & 60 & \\
\hline & Other & 220 & & 230 & 185 & 270 & & 220 & \\
\hline
\end{tabular}

Table 2. Proportion (\%) of different species/groups.

\begin{tabular}{|c|c|c|c|}
\hline Group & Species & \% by species & \% by group \\
\hline \multirow{15}{*}{ Fin Fishes } & Bregmerossis sp. & 1.28 & \multirow{15}{*}{77.03} \\
\hline & Aureus sp. & 0.4 & \\
\hline & Cynoglossus sp. & 0.51 & \\
\hline & Coila sp. & 6.37 & \\
\hline & Escualusa thorakata & 0.69 & \\
\hline & Harpodon sp. & 28.41 & \\
\hline & Johuinius sp. & 21.88 & \\
\hline & Lepturacanthus sp. & 0.12 & \\
\hline & Mugil sp. & 0.24 & \\
\hline & Polynemus paradesius & 10.28 & \\
\hline & Platycephalus & 0.27 & \\
\hline & Silago sp. & 0.30 & \\
\hline & Satiphina sp. & 1.78 & \\
\hline & O. rubicandus & 4.50 & \\
\hline & Penaeus japonicus & 8.60 & \\
\hline \multirow{3}{*}{ Shrimp } & P. merguensis & 3.71 & \multirow{3}{*}{19.82} \\
\hline & P. stylifera & 0.08 & \\
\hline & Other & 7.43 & \\
\hline Crab & & 3.19 & 3.15 \\
\hline
\end{tabular}


3.2. Estimation of total catch

Average catch per boat per trip was found $8.8 \mathrm{~kg}$ with highest $25 \mathrm{~kg}$ in the month of October and lowest $(2 \mathrm{~kg})$ in the month of August at Kumira. Average catch per boat per day were found $16.6 \mathrm{~kg}$ in Kumira. The highest total catch per boat per day $(50 \mathrm{~kg}$ ) was found in the month of October in Kumira. The lowest catch was found $(2 \mathrm{~kg}$ ) in August for Kumira. The average total catch per boat per month was $498 \mathrm{~kg}$ with the highest $(1500 \mathrm{~kg})$ in the month of October and the lowest $(60 \mathrm{~kg})$ in the month of August at Kumira. The average total catch per landing center per month was found $14805 \mathrm{~kg}$ with the highest $(49500 \mathrm{~kg})$ in the month of October and lowest $(600 \mathrm{~kg})$ in the month of August at Kumira (Table 3). During the month July and August most of the fishermen were engaged in Hilsa fishing with the Hilsa gill net. Their target catch was Hilsa sp. and usually they do not operate ESBN at that time. As a result, the total catch was found lowest in those months.

Table 3. Catch and effort estimation of the ESBN fishery in the Kumira.

\begin{tabular}{|c|c|c|c|c|c|c|c|c|c|c|c|}
\hline Months & $\begin{array}{l}\text { Catch } \\
\text { (kg)/boat } \\
\text { /trip }\end{array}$ & $\begin{array}{l}\text { Trip } \\
\text { /day }\end{array}$ & $\begin{array}{l}\text { Catch } \\
\text { (kg) } \\
\text { /boat } \\
\text { /day }\end{array}$ & $\begin{array}{l}\text { Total } \\
\text { catch } \\
\text { (kg) } \\
\text { /boat } \\
\text { /month }\end{array}$ & $\begin{array}{l}\text { No. of } \\
\text { boat } \\
\text { operated/ } \\
\text { day }\end{array}$ & $\begin{array}{l}\text { Total } \\
\text { catch }(\mathrm{kg}) / \\
\text { landing } \\
\text { center/ } \\
\text { month }\end{array}$ & $\begin{array}{l}\text { Net/ } \\
\text { boat }\end{array}$ & $\begin{array}{l}\text { Catch } \\
(\mathrm{kg}) / \\
\text { net/day }\end{array}$ & $\begin{array}{l}\text { Fisher } \\
\text { men } \\
\text { / boat }\end{array}$ & $\begin{array}{l}\text { Catch } \\
\text { (kg)/ } \\
\text { fisherman } \\
\text { /day }\end{array}$ & $\begin{array}{l}\text { Catch } \\
\text { (kg)/ } \\
\text { fisherman } \\
\text { /month }\end{array}$ \\
\hline May & 15 & 2 & 30 & 900 & 28 & 25200 & 4 & 7.5 & 6 & 5 & 150 \\
\hline June & 5 & 1 & 5 & 150 & 21 & 3150 & 4 & 1.25 & 4 & 1.25 & 37.5 \\
\hline July & 3 & 1 & 3 & 90 & 22 & 1980 & 5 & 0.6 & 4 & 0.75 & 22.5 \\
\hline Aug & 2 & 1 & 2 & 60 & 10 & 600 & 4 & 0.5 & 4 & 0.5 & 15 \\
\hline Sept & 4 & 2 & 8 & 240 & 15 & 3600 & 6 & 1.33 & 5 & 1.6 & 48 \\
\hline Oct. & 25 & 2 & 50 & 1500 & 33 & 49500 & 6 & 8.33 & 5 & 10 & 300 \\
\hline Nov. & 21 & 2 & 42 & 1260 & 31 & 39060 & 5 & 8.4 & 4 & 10.5 & 315 \\
\hline Dec & 13 & 2 & 26 & 780 & 32 & 24960 & 6 & 4.33 & 6 & 4.33 & 129.9 \\
\hline Average & 8.8 & 1.3 & 16.6 & 498 & 19.2 & 14805 & 4 & 3.224 & 3.8 & 3.393 & 101.79 \\
\hline
\end{tabular}

\subsection{Effort estimation}

Four fishermen operated 4 nets per trip on an average at Kumira. The average catch per net per day was found $3.22 \mathrm{~kg}$ with the highest $8.33 \mathrm{~kg}$ in the month of October and the lowest $0.5 \mathrm{~kg}$ in the month of August at Kumira. The average catch per fishermen per day was found $3.39 \mathrm{~kg}$ at Kumira. The average catch per fishermen per month was found $101.79 \mathrm{~kg}$ at Kumira. The highest average catch per fishermen per month was found $315 \mathrm{~kg}$ at Kumira in November. The lowest catch per fishermen per month was found $15 \mathrm{~kg}$ at Kumira in August (Table 3).

\subsection{Cost and earning}

The price of the mixed species of fish and shrimp ranged from Tk. 25 to 45 per kg in Kumira. The highest value of Tk. 45 of mixed species was found in the month of July and the lowest Tk. 25 in October. Average cost per boat per month was about 7,813 Tk in Kumira. Maximum cost was 11,500 Tk during high fishing season for greater involvement of crew and fuel. Average sale per month was found over 18,713 Tk in Kumira with the highest sale of 37,800 Tk in November at Kumira. The fish price per $\mathrm{kg}$ of mixed species was $35.5 \mathrm{Tk}$ and 28 Tk in that month. The lowest income was showed during the month of August (Table 4).

Table 4. Comparison cost and earning per boat for ESBN catches in Kumira.

\begin{tabular}{llllll}
\hline Months & $\begin{array}{l}\text { Cost/boat/month } \\
\text { (Tk) }\end{array}$ & $\begin{array}{l}\text { Total catch } \\
\text { (kg)/boat/month }\end{array}$ & $\begin{array}{l}\text { Market price of mixed } \\
\text { species (Tk/kg) }\end{array}$ & Total sale (Tk.) & Income/month \\
\cline { 2 - 6 } & Kumira & Kumira & Kumira & Kumira & Kumira \\
\hline May & 10000 & 900 & 28 & 25200 & 15200 \\
June & 6500 & 160 & 42 & 6720 & 220 \\
July & 5000 & 120 & 45 & 5400 & 400 \\
August & 2000 & 60 & 42 & 2520 & 520 \\
September & 8500 & 240 & 25 & 9600 & 1100 \\
October & 11500 & 1500 & 30 & 37500 & 26000 \\
November & 10000 & 1260 & 32 & 37800 & 27800 \\
December & 9000 & 780 & 35.5 & 24960 & 15960 \\
Average & 7813 & 627.5 & & 18713 & 10900 \\
\hline
\end{tabular}




\section{Discussion}

The average catch composition of Bombay duck (Harpodon neherius) was found highest in the present investigation followed by Shrimp. Ahmed (1981) and Munga et al. (2014) found highest result (9.64\%) of the catch composition of Shrimp; Jit et al. (2014) investigated contribution (76\%) to total catch in shark species; Chowdhury et al. (2011) mentioned 21.5-31.5\% of marine catch in Naaf river; Hossain et al. (2012) mentioned Oxyurichthys microlepis, Hemiarius sona, Arius thalassinus, Batrachocephalus mino and Arius caelatus are the major contributory species. Oh et al. (2010) found similar result in Malaysian coast. The highest catch rate and composition was found in the month of October which is known as the most suitable season for fishing in Bangladesh. The catch rate and composition was found lower in the winter season which is very identical with the Khan (1982) report and with report Islam et al. (1992); FAO (1982); Jit et al. (2014) Ghosh et al. (2016); Kar and Chakraborty, (2011) also reported that Acetees sp, Gobiodies and Bombay duck are the most dominant species in ESBN. A very recent study done by Begum (2004) on the Salimpur coast showed that finfish comprises highest followed by shrimp, crab and other invertebrates which is almost coincide with present study. In the present investigation daily average production per boat was found $16.6 \mathrm{~kg}$ for Kumira which disagrees with the daily average production of $56.55 \mathrm{~kg}$ in Kumira as reported by Islam et al. (1992). Begum (2004) and Chakma (2004) found average catch per boat was $32 \mathrm{~kg}$ and $23.08 \mathrm{~kg}$ respectively and these reports also differ from the results of the present study. Khan et al. (1997); Habib et al. (2014); Ahmed (1991) and Rabbani et al. (2017); Nielsen et al. (2018); Nabi and Ullah, (2012) studied on the population parameters of these investigated area and found over exploitation of the most commercial species and this also agrees with the present study. Islam (1987) found the highest average daily production $(231.68 \mathrm{~kg})$ in the month of October; this agrees with the present investigation the highest average daily production was found in the month of October in Kumira. Though the amount of production greatly varied with the result of Hossain et al. (2012) and Mondal et al. (2018); but the peak season was found the same. A details investigation regarding catch rate of Behundi Net was conducted by Islam et al. (1993). In that investigation the highest catch rate $(15.10 \mathrm{~kg})$ was observed in Moheshkhali, and the lowest in Kaligange (2.35 kg), similar result was also observed by Barua et al. (2014); while Kumira had $(3.10 \mathrm{~kg})$. The highest catch rate of $25 \mathrm{Kg}$ at Kumira which are higher than the result of Islam et al. (1993). In the present investigation the average numbers of net per boat were 4 for Kumira while according to Akerman (1986), average number of net per boat was $1.17 \mathrm{Kg}$. This report seems to be erroneous as from the verbal discussion it was confirmed that some boats used to 6 to 8 nets in single trip which is similar with the study of (Islam and Haque, 2004). The average catch per fishermen per day was found $3.39 \mathrm{~kg}$ for Kumira and these results coincide with $4.22 \mathrm{Kg}$ as reported by Begum (1994) and $8 \mathrm{Kg}$ as reported by Chakma (1994).

\section{Conclusions}

Estuarine Setbagnet (ESBN) fishing is organized as a family enterprise, with active participation of the family in fishing, marketing and processing. Although it is practiced almost round the year, fishermen seasonally shift to other fisheries also i.e. Hilsha fishing by gill net. They also undertake a variety of non-fishing activities as part time source of additional income.

\section{Conflict of interest}

None to declare.

\section{References}

Ahmed M, 1991. A model to determine benefits obtainable from the management of riverine fisheries of Bangladesh. ICLARM Tech. Rep. 28. p.133.

Ahmed MK, 1981. Behundi net fishery in the brackisheater area of Satkhira with emphasis on bionomics and mortalities of shrimps. Research Report No.3. Freshwater Fisheries Research Station, Comilla, Bangladesh. pp. 45-52.

Akerman SE, 1986. The coastal set bagnet fishery of bangladesh-fishing trials and investigations. FAO, Madras, India. p. 29.

Alam MM, 2001. Impending issues in coastal set bag net fishery management in Bangladesh. Proceedings of the 12th Biennial Coastal Zone Conference, Cleveland, OH, USA.

Amin SMN, R Ara and M Zafar, 2006. Conservation of marine and coastal shrimp resources and sustainable aquaculture. Res. J. Fish. Hydrobio., 1: 18-22.

Barua S, E Karim and NM Humayun, 2014. Present status and species composition of commercially important finfish in landed trawl catch from Bangladesh marine waters. Int. J. Pure App. Zoolo., 2: 150-159. 
Begum F, 2004. The status of small-scalee fishery of north Salimpur, A coastal village of Chittagong, Bangladesh. MSc Thesis, Institute of Marine Sciences, University of Chittagong. p. 83.

Chakma P, 2004. On the study of status of small-scale fishery of south Salimpur coastal village of Chittagong, Bangladesh. MSc Thesis, Institute of Marine Sciences, University of Chittagong. p. 71.

Chowdhury MSN, MS Hossain, NG Das and P Barua, 2011. Small-scale fishermen along the Naaf River, Bangladesh in crisis: A framework for management. Mesopot. J. Mar. Sci., 26: 146 -169.

FAO, 1982. Report of the fourth session of the sub-committee on management of resources within the limits of national jurisdiction. Dakar, Senegal, 8-11 June 1982. p. 34.

Ghosh SK, MK Ahsan, MK Ahmmed, SI Ahmed, MM Hasan and M Kamal, 2016. Catch assessment of artisanal marine fishing gears in Cox's Bazar and Teknaf of Bangladesh. Prog. Agri., 27: 228-234.

Habib A, 2010. Possible economic impact on coastal fish stock resources in Bangladesh in the case of climate change. Master Thesis. Department of Fisheries and Aquaculture. University of Tromso, Norway and Nha Trang University, Vietnam. pp. 1-37.

Habib A, MH Ullah and NN Duy, 2014. Bioeconomics of commercial marine fisheries of Bay of Bengal: Status and direction. Econ. Res. Int., 2014: 538074.

Hossain MS, NG Das, S Sarker and MZ Rahaman, 2012. Fish diversity and habitat relationship with environmental variables at Meghna river estuary, Bangladesh. Egyptian J. Aqua. Res., 38: 213-226.

Hussain MG and ME Hoq, 2010. Sustainable management of fisheries resources of the Bay of Bengalcompilation of national and regional workshop reports. Support to Sustainable Management of the BOBLME Project, Bangladesh Fisheries Research Institute. SBOBLMEP Pub./Rep. 2. p. 122.

Hussain MM, 1994. Status of development of the fishery and seafood processing industry in Bangladesh. Proceeding of a workshop on "Sustainable development of marine fisheries resources in Bangladesh", Cox's Bazar, Bangladesh. pp. 65-85.

Islam AKMN, 1976. Contribution to the study of marine algae of Bangladesh. Biblotheca Phycologia, 19: 1253.

Islam MM, MM Shamsuzzamana, MMH Mozumder, X Xiangminb, Y Mingb and MAS Jewel, 2017. Exploitation and conservation of coastal and marine fisheries in Bangladesh: Do the fishery laws matter? Marine Policy, 76: 143-151

Islam MS and M Haque, 2004. The mangrove-based coastal and near shore fisheries of Bangladesh: ecology, exploitation and management. Rev. Fish Biol. Fish., 14: 153-180.

Islam MS, 1987. Study of catch composition of behundi net (set bagnet in relation to some ecological parameters in the Naf River estuary). Marine Fisheries Survey Management \& Development Project. Cox's Bazar. Bangladesh. Mimeo. pp. 4-32.

Islam MS, 1994. Socioeconomic status of marine fishermen and their upliftment. Proceeding of workshop on "Sustainable development of marine fisheries resources in Bangladesh", Cox's Bazar, Bangladesh. pp. 5856.

Islam MS, 2003. Perspectives of the coastal and marine fisheries of the Bay of Bengal, Bangladesh. Ocean Coast. Man., 46: 763-796.

Islam MS, MG Khan, SA Quayum and SZA Chowdhury, 1992. Estuarine set bag net fishery of Bangladesh. Marine Fisheries Survey and management and Development project, Dept. of Fisheries, Chittagong, Bangladesh. pp. 25-89.

Islam MS, MG Khan, SA Quayum and SZA Chowdhury, 1993.The estuarine set bag net fishery in studies of interactive marine fisheries of Bangladesh. Bay of Bengal programme, Madras, India.BOBP/WP/89.

Jit RB, MF Alam, MG Rhaman, NK Singha and A Akhtar, 2014. Landing trends, species composition and percentage composition of Sharks and Rays in Chittagong and Cox's Bazar, Bangladesh. Glob.J. Sci. Front. Res., 14: 070403-079999.

Johnson JE and DJ Welch, 2009. Marine fisheries management in a changing climate: A review of vulnerability and future options. Rev. Fish. Sci., 18: 106-124.

Kar TK and K Chakraborty, 2011. A bioeconomic assessment of the Bangladesh shrimp fishery. World J.Model. Simu., 7: 58-69.

Khan MG, 1982. Pilot survey of set bag net fishery of Bangladesh. BOBP/WP/34.Rome. p. 26.

Khan MG, 1994. Present status and future plan for sustainable marine resources development. Proceeding of a workshop on "Sustainable development of marine fisheries resources in Bangladesh", Cox's Bazar, Bangladesh. pp. 30-37. 
Khan MG, MS Islam, MG Mustafa, MN Sada and ZA Chowdhury, 1997. Biosocioeconomic assessment of the effect of the estuarine set bag net on the marine fisheries of Bangladesh. Bay of Bengal Program/WP/94. p. 28.

Lodge MW, D Anderson, T Løbach, G Munro, K Sainsbury, A Willock, 2007. Recommended best practices for regional fisheries management organizations report of an independent panel to develop a model for improved governance by regional fisheries management organizations. The Royal Institute of International Affairs.UK. pp. $1-150$.

Matin A, MB Hossain, M Iqbal, MM Billah, AA Asif and MM Billah, 2018. Diversity and abundance of Macrobenthos in a subtropical estuary, Bangladesh. Species, 19: 140-150.

Miah MNU, MM Shamsuzzaman, AHA Rashid, PP Barman, 2015. Present status of coastal fisheries in sitakunda coast with special reference on climate change and fish catch. J. Aquac. Res. Dev., 6: 362.

Mondal MAI, MA Kader, AH Choudhury, MG Mustafa, MRU Nabi, MM Billah, AA Asif and AAM Siddiqui, 2018. Socio-economic uplifting analysis of ESBN fishery of the coastal villages, Kumira and Kattoli, Chittagong, Bangladesh. Int. J. Res. Grant., 6: 248-263.

Munga CN, S Mwangi, H Ong'anda, R Ruwa, J Manyala, JC Groeneveld, E Kimani and A Vanreusel, 2014. Fish Catch composition of artisanal and bottom trawl fisheries in Malindi-Ungwana Bay, Kenya: A cause for conflict? Western Indian Ocean J. Mar. Sci., 13: 177-188.

Nabi MRU and Ullah MH, 2012. Effects of set bagnet fisheries on the shallow coastal ecosystem of the Bay of Bengal. Ocean Coastal Man., 67: 75-86.

Nielsen JR, E Thunberg, DS Holland, JO Schmidt, EA Fulton, F Bastardie and S Waldo, 2018. Integrated ecological-economic fisheries models - evaluation, review and challenges for implementation. Fish and Fisheries, 19: 1-29.

Nuruzzaman AKM, 1990. Problems and potentials for development of inland capture fisheries of Bangladesh. A paper presented at the world aquaculture '90 conference, held in Canada, June, 1990.

Oh SY, A Arshad, SP Pang and SMN Amin, 2010. Catch Composition of Estuarine Set Bag Net fishery in the coastal area of pontian, Johor, Peninsular Malaysia. J. Biol. Sci., 10: 247-250.

Pauly D and D Zeller, 2016. Catch reconstructions reveal that global marine fisheries catches are higher than reported and declining. Nature Comm., 7: 10244.

Rabbani MG, MA Khan, MS Islam and RY Lucky 2017. Technical efficiency of the set bag net fishery in Bangladesh: An application of a stochastic production frontier model. The Agriculturists, 15: 59-65.

Shafi M and Quddus MMA, 1982. Bangladesher Matshaw Sampad, Bangla academy, Dhaka, pp. 307-308.

Thomson KT, D Jahan and S Hussain, 1993. Socioeconomic conditions of the estuarine set bag net fisher folk in Bangladesh. (BOBP/WP/90). p. 27.

Ullah H, D Gibson, D Knip, K Zylich and D Zeller, 2014. Reconstruction of total marine fisheries catches for Bangladesh: 1950-2010. Working Paper \#2014 - 15. The University of British Columbia. pp. 1-10.

Viswanathan KK and KM Jahan, 2010. Noncompliance a major threat in fisheries management-experiences from the artisanal coastal fisheries of Bangladesh. Universiti Utara Malaysia, WorldFIsh Center. MPRA Paper No. 32330.

World Bank, 1998. Bangladesh Fisheries Sectors Review Report No. 8830-BD. 